\title{
PENGARUH PENAMBAHAN BAHAN ADDITIF PADA PRODUK PENCUCI TANGAN BERBAHAN ASAP CAIR CANGKANG SAWIT TERHADAP DAYA HAMBAT PERTUMBUHAN BAKTERI
}

\section{THE EFFECT OF ADDITIVE MATERIAL ON HAND SANITIZER FROM LIQUID SMOKE PALM TO BACTERIAL GROWTH INHIBITORY ACTIVITY}

\author{
Fauziati \\ Balai Riset dan Standardisasi Industri Samarinda \\ JIn. MT. HARYONO N0. 1 \\ Email :. fauziati.baristand@gmail.com
}

Naskah diterima 23 September 2013, disetujui 25 Nopember 2013

\begin{abstract}
ABSTRAK
Asap cair cangkang sawit dapat digunakan sebagai bahan antiseptik pencuci tangan . Metode penelitian dilakukan dengan menggunakan 2 (dua ) factor yaitu factor A sebagai pengental (polyglicol) dengan 3 (tiga) taraf yaitu $\mathrm{a}_{1} 12 \%, \mathrm{a}_{2} \quad 16 \%$ dan $\mathrm{a}_{3} 20 \%$ dan factor $\mathrm{B}$ sebagai pelembut ( glyserin) dengan 3 (tiga) taraf yaitu $b_{1} 0,5 \%, b_{2} 1 \%$ dan $b_{3} 1,5 \%$. Penambahan bahan aditif yaitu pengental (polyglicol) dan pelembut ( glyserin ) pada produk antiseptik berbahan asap cair cangkang sawit memberikan pengaruh terhadap daya hambat pertumbuhan bakteri . Pada penambahan bahan pengental $16 \%$ dan pelembut $1,50 \%$ memberikan daya hambat pada pertumbuhan bakteri yang terbaik terhadap bakteri Staphylococus aureus dengan kategori kuat dan bakteri Salmonella thipy dengan kategori kuat dengan pH 3,5 dan viscositas 0,4 dPas . Hasil analisa swab test terhadap panelis menunjukkan adanya perbedaan terhadap jumlah koloni bakteri sebelum dan sesudah diusap dengan produk pencuci tangan berbahan antiseptik asap cair Pengurangan jumlah koloni bakteri pada tangan panelis sebelum dan setelah diusap masing-masing $8,3 \%$ dan $96,75 \%$.
\end{abstract}

Kata kunci : Asap Cair Cangkang Sawit, Bahan Aditif, Antiseptik, Pencuci Tangan

\begin{abstract}
Palm shell liquid smoke can be used as an antiseptic hand cleaner. The research method is done by using two (2) factors that factor $A$ as a thickener (polyglicol) with three (3) levels ie $12 \%$ a1, a2 and a3 16\% 20\% and factor $B$ as a softener (glyserin) with three (3) level ie $0.5 \%$ b1, b2 and b3 $1 \%$ to $1.5 \%$. The addition of the thickener additives (polyglicol) and softener (glyserin) in antiseptic products made from palm shell liquid smoke to give effect to the inhibition of bacterial growth. In addition $16 \%$ thickener and softener gives $1.50 \%$ inhibition of the growth of bacteria is best to Staphylococus aureus bacteria with strong category and Salmonella bacteria thipy with strong category with a $\mathrm{pH}$ of 3.5 and a viscosity of 0.4 DPAs The results of the analysis of a swab test the panelists indicate a difference in the number of bacterial colonies before and after swabbed with antiseptic products based hand wash liquid smoke reduction in the number of bacterial colonies on hand before and after the panelists swabbed respectively $8.3 \%$ and $96.75 \%$
\end{abstract}

Keywords : Liquid Smoke Shell Oil, additive materials, antiseptic, Hand Wash 


\section{PENDAHULUAN}

$\mathrm{P}$ otensi lahan perkebunan kelapa sawit Nasional seluas 9,07 juta Ha dengan produksi CPO sebesar 23,52 juta ton (Kementan,2012).

Sedangkan perkembang-an produksi tanaman kelapa sawit di Kalimantan Timur terus mengalami peningka-tan, pada tahun 2012 memiliki luas areal tanaman sawit seluas 800,700 $\mathrm{Ha}$ dan menghasilkan Tandan Buah Segar (TBS) sebesar 4.471.556 ton dan terdapat 49 pabrik CPO di Kalimantan Timur ( Bappeda Prop. Kaltim ,2013 ).

Limbah padat pabrik kelapa sawit dengan kapasitas 100 ribu ton tandan buah segar (TBS) pertahun menghasilkan sekitar 6 (enam) ribu ton cangkang sawit, 12 (dua belas) ribu ton serabut dan 23 (Dua puluh tiga) ton tandan buah kosong (Marpaung, DS 2009). Sehingga dari 4.471.556 ton TBS yang dihasilkan di Kalimantan Timur akan dihasilkan cangkang kelapa sawit sekitar \pm 268.293 ton.

Cangkang kelapa sawit memiliki sifat fisik yang keras dan menyerupai tempurung kelapa dan penggunaannya selama ini sebagai bahan bakar boiler, biodiesel, biopellet, arang aktif dan asap cair. Oleh karena itu, limbah ini sangat berpotensi jika dikembangkan menjadi produk yang bermanfaat dan memberi nilai tambah dari aspek ekonomi serta ramah lingkungan.

Pengolahan cangkang sawit dengan teknik pirolisis sangat menguntungkan karena semua produknya dapat dimanfaatkan untuk berbagai keperluan, adapun keuntungan pengolahan limbah cangkang sawit dengan metode ini selain mampu meminimalisasi pencemaran udara juga dihasilkan produk berupa arang dan asap cair yang dapat dimanfaatkan. Asap cair mengandung kelompok senyawa fungsional seperti asam 10,20\%, fenol $4,13 \%$ dan karbonil $11,30 \%$ yang mempunyai peranan penting dalam pengendalian aroma, mikroorganisme, pengobatan dan dapat menghambat pertumbuhan bakteri dan jamur (Darmadji
P, dkk, 2010). Bahan antiseptik pembersih tangan dipasaran pada umumnya menggunakan Triclosan (2,4,4-trichlorohydroksidiphenil ether) yaitu suatu agen kimia antibakteri yang banyak digunakan dalam berbagai produk seperti sabun, deodorant, kosmetik dan antiseptik pembersih tangan), yang bersifat karsinogenik.

Saat ini terdapat banyak pilihan antiseptik yang ada di pasaran. Bentuk dari sediaan yang ada contohnya antara lain bentuk gel, lotion, sabun cair, atau sabun batang. Pada beberapa sediaan antiseptik, tidak hanya antiseptik pembersih tangan, zat aktif yang umumnya digunakan yaitu Triklosan. Triklosan atau irgasan DP 300 merupakan antibakteri yang banyak digunakan dalam berbagai produk sepeti sabun, deodorant, kosmetik, lotion pembersih, pasta gigi.

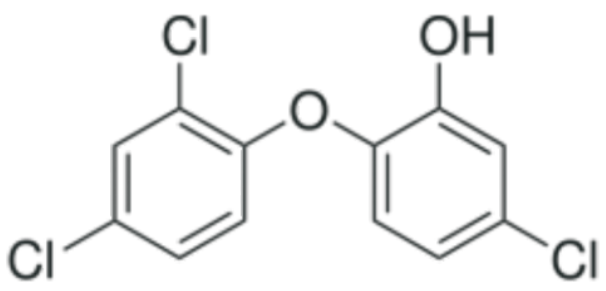

Gambar 1. Struktur kimia Triklosan

Triklosan yang banyak digunakan dalam beberapa produk tersebut diketahui banyak mencemari air (Singer H, 2002 dalam Kelompok Studi Propetik Fakultas Farmasi UGM 2010). Antara tahun 1999 dan 2000, triklosan banyak ditemukan dalam jumlah konsentrasi paling tinggi dalam pemeriksaan air sungai yang tercemar (Colpin, 2002)

Triklosan dapat diserap kulit, mulut, dan hidung dalam waktu beberapa menit saja setelah pemakaian. Manusia juga dapat tercemari melalui makanan terutama ikan atau hewan air lainnya. Triklosan akan terakumulatif (Bennet ER, 2009). Selain itu triklosan juga dapat mencemari air susu ibu yang nantinya dapat mempengaruhi perkembangan bayi (Anonim, 2010) Antiseptik alami dari asap cair cangkang 
sawit berpotens iuntuk digunakan sebagai subtitusi dari bahan antiseptik kimiawi ,karena asap cair cangkang sawit mengandung kelompok senyawa fungsional seperti asam asetat $10,20 \%$, fenol $4,13 \%$ dan karbonil $11,30 \%$ yang mempunyai peranan penting dalam pengendalian aroma ,mikroorganisme, pengobatan dan dapat menghambat pertumbuhan bakteri dan jamur (Darmadji P, dkk, 2010).

Produk antiseptik pencuci tangan tersebut dapat dibuat dengan menggunakan bahan antiseptik asap cair cangkang sawit dengan menambahkan bahan additif pengental (Polyglicol) dan pelembut (glyserin) dan bahan lain seperti pewangi.

Polyglicol atau Polyethilen glycol (PEG) adalah bahan yang digunakan sebagai pengental, plastisiser, humectan (pelembab) adalah senyawa higroskopis yang digunakan untuk menjaga kelembaban kulit. dan sebagai bahan farmasi, tidak berwarna, bersifat kental, anti bakteri larut atau sebagian larut dalam air dan lebih larut dalam alkohol dan pelarut organik lainnya dengan rumus kimia $\mathrm{HOCH}_{2}(\mathrm{CH} 2 \mathrm{OCH} 2) \mathrm{nCH} 2 \mathrm{OH}$. Fungsi dari gliserin adalah disamping sebagai humectan (pelembab) juga berfungsi sebagai bakteriostatik atau senyawa yang berperan menghambat laju pertumbuhan bakteri . (Lewis RJ., Sr, 2002).

Glyserin dengan rumus kimia $\mathrm{C} 3 \mathrm{H} 6 \mathrm{OH}$ : adalah senyawa kimia jernih, tidak berwarna, agak kental hygroskopis, larut dalam air dan alkohol, tidak larut dalam eter, benzene dan kloroform dan bersifat volatile yang digunakan sebagai plastisiser, kosmetik, khusus untuk sabun sebagai anti bakteri. Sehingga dengan penambahan bahan aditif polyglicol sebagai pengental dan glyserin sebagai pelembut memberikan pengaruh terhadap Salmonella thipy dengan diameter daya hambat lebih besar $10 \mathrm{~mm}$ (Herwig ,1979)

Produk antiseptik pencuci tangan yang dihasilkan kemudian dilakukan uji daya hambat terhadap pertumbuhan bakter pada 3 (tiga) jenis bakteri yaitu $S$. aureus, E. coli dan Salmonella typhi. Kemampuan daya hambat produk antiseptik pencuci tangan dengan bahan asap cair cangkang sawit dengan penambahan bahan additif pengental dan pelembut diuji dengan metode swab test.

$E$. coli adalah bakteri yang banyak ditemukan didalam usus besar manusia sebagai flora normal. Bakteri ini merupakan batang gram negatif yang tumbuh dengan mudah pada medium nutrien sederhana dan dapat menyebabkan diare akut. $S$ aureus merupakan sel gram positif yang berbentuk dan berbentuk bulat dan kebanyakan galur ini adalah koagulasi positif. Bakteri ini tidak bergerak dan tidak berspora, tertata seperti anggur menghasilkan koagulasi dan dapat menyebabkan keracunan makanan, infeksi kulit ringan sampai berat (Rostinawati $T$, 2009).

Salmonella typhi adalah bakteri gram negatif berbentuk batang ,bakteri ini dapat mati pada suhu $56{ }^{\circ} \mathrm{C}$, tumbuh pada suasana $\mathrm{pH}$ 6-8 dan pertumbuhan optimumnya pada $37,5^{\circ} \mathrm{C}$. ( Rostinawati T, 2009 ).

Menurut Herwig (1979) dalam Titik Pujilestari, 2010), bahwa suatu bahan memiliki daya hambat pertumbuhan bakteri / mikroba sangat kuat bila diameter hambatnya $>20 \mathrm{~mm}$, kuat 10-20 $\mathrm{mm}$ dan sedang 5-10 $\mathrm{mm}$ serta lemah $<5$ $\mathrm{mm}$.

Tujuan penelitian ini adalah untuk mengetahui pengaruh penambahan bahan pengental (Polyglicol) dan pelembab (glyserin) terhadap pertumbuhan bakteri S. aureus, E. coli dan Salmonella typhi pada produk antiseptik pencuci tangan berbahan dasar asap cair cangkang sawit

\section{Metode Penelitian}

\section{Bahan dan Alat}

Bahan penelitian adalah asap cair hasil redistilasi bertingkat pada suhu $180^{\circ} \mathrm{C}-200^{\circ} \mathrm{C}$, pengental (polygel), dan 
pelembut (glyserin), alcohol, pewangi dan pewarna dan perbandingan asap cair dan alcohol 40\%:60\%. Media : Plate Count Agar, Nutrient Agar, dan Saboroud Dextrose Agar (SDA).

Peralatan yang digunakan adalah Alat pyrolisis asap cair cangkang sawit, alat destilasi (untuk pemurnian asap cair ), mixer, pH dan Viscosimeter, Furnace, GC MS Angilent Technologies type GC 6890N, MS 5973 dan peralatan uji lainnya.

\section{Rancangan Percobaan}

Penelitian dilakukan dengan menggunakan 2 faktor yaitu faktor $A$ sebagai pengental (Polygicol) dan faktor $B$ sebagai pelembut (gliserin).

Faktor A terdiri dari 3 taraf : $a_{1}$. $12 \%, a_{2} .16 \%$ dan $a_{3} .20 \%$. Faktor $B$ terdiri dari 3 taraf : $b_{1} \quad 0,5 \%, b_{2} 1 \%$ dan $b_{3}$ $1,5 \%$.

Kedua faktor tersebut diperoleh 9 perlakuan yang mana masing-masing dilakukan 3 kali ulangan .

\section{Prosedur Penelitian.}

\section{Pembuatan Biang Pengental dan pelembut.}

Biang pengental disiapkan melalui pelarutan 1 gram Polygicoll dalam 50 gram air panas diaduk hingga homogen. Sedangkan pelembut ditambahkan langsung pada pembuatan produk. Komposisi perlakuan adalah seperti yang terlihat pada Tabel 1 dengan penggunaan formulasi dasar antiseptik terpilih .

\section{Pembuatan Produk Antiseptik}

Produk antiseptik dibuat dengan memformulasikan komposisi asap cair dan alkohol dengan penambahan pengental Polyglicoll yang terdiri dari 3 taraf yaitu $a_{1}$ $12 \%, a_{2} 16 \%$ dan $a_{3} 20 \%$ dan pelembut Gliserin yang terdiri dari 3 (tiga) taraf yaitu $b_{1} .0,5 \%, b_{2} 1 \%$ dan $b_{3} 1,5 \%$ selanjutnya dilakukan pengadukan dan pemanasan hingga homogen dan ditambahkan pewarna dan pewangi sesuai selera. Pengaruh daya hambat setelah penambahan bahan additif seperti pengental (polyglicol) dan gliserin (pelembut) diuji dengan $\mathrm{pH}$,dan daya hambat terhadap bakteri Ecolli, Staphilococus aureus, Salmonella thypi dan viscositas.

Pengurangan bakteri maupun jamur yang terdapat pada tangan dan untuk mengetahui kemampuan daya hambat produk antiseptik pencuci tangan dengan bahan antiseptik asap cair cangkang sawit diuji dengan penambahan bahan additif pengental dan pelembut terhadap pertumbuhan bakteri maka dilakukan uji swab test.

Perhitungan angka bakteri yang terdapat pada tangan sebelum dibersihkan dengan produk pencuci tangan asap cair cangkang sawit dengan penambahan bahan additif pengental (polyglicol) dan pelembut (gliserin), dilakukan pemeriksaan menurut cara yang tertera dalam (Slack et al, 1971) yaitu: sebelum diperiksa kedua telapak tangan responden saling digosokgosokkan agar supaya kandungan bakteri dikedua telapak tangannya homogen, kemudian dengan swab kapas steril yang telah dibasahi dengan larutan $\mathrm{NaCl} 0,9 \%$ diusapkan atau disapukan dengan cukup kuat pada telapak tangan responden, berlawanan arah dengan garis telapak tangan. Swab kapas tersebut kemudian diusapkan di atas plat media Nutrien Agar dalam cawan petri,secara merata dan menyeluruh. Cawan petri tersebut kemudian diinkubasi pada suhu $37^{\circ} \mathrm{C}$ selama 24 Jam. Setelah itu koloni bakteri yang tumbuh dihitung dan dicatat.

Perhitungan angka bakteri yang terdapat pada tangan yang telah dibersihkan dengan pencuci tangan asap cair cangkang sawit. Setelah percobaan diatas dilakukan, maka telapak tangan responden segera dibersihkan dengan cairan pencuci tangan. Setelah 35 detik swab kapas steril yang telah dibasahi dengan larutan $\mathrm{NaCl} \quad 0,9 \%$ diusapkan dengan cukup kuat pada telapak tangan responden yang telah dibersihkan, dengan 
berlawanan arah dengan garis telapak tangan.

Swab kapas tersebut kemudian diusapkan diatas lempeng media Nutrient Agar dalam cawan petri, secara merata dan menyeluruh. Cawan petri tersebut kemudian diinkubasi pada suhu $37^{\circ} \mathrm{C}$ selama 24 Jam. Hasil inkubasi diamati dan koloni bakteri yang tumbuh dihitung dan dicatat. Komposisi perbandingan asap cair ,etanol,pengental dan pelembut seperti tertera pada tabel 1.

Tabel 1. Komposisi Perbandingan Asap cair, Etanol, Pengental dan Pelembut.

\begin{tabular}{cccccc}
\hline No & Kode & $\begin{array}{c}\text { Asap } \\
\text { Cair } \\
(\%)\end{array}$ & $\begin{array}{c}\text { Etanol } \\
(\%)\end{array}$ & $\begin{array}{c}\text { Pengental } \\
(\%)\end{array}$ & $\begin{array}{c}\text { Pelembut } \\
(\%)\end{array}$ \\
\hline 1. & $\mathrm{a}_{1} \mathrm{~b}_{1}$ & 40 & 60 & 12 & 0,5 \\
2. & $\mathrm{a}_{1} \mathrm{~b}_{2}$ & 40 & 60 & 12 & 1.0 \\
3. & $\mathrm{a}_{1} \mathrm{~b}_{3}$ & 40 & 60 & 12 & 1,5 \\
4 & $\mathrm{a}_{2} \mathrm{~b}_{1}$ & 40 & 60 & 16 & 0,5 \\
5 & $\mathrm{a}_{2} \mathrm{~b}_{2}$ & 40 & 60 & 16 & 1,0 \\
6 & $\mathrm{a}_{2} \mathrm{~b}_{3}$ & 40 & 60 & 16 & 1,5 \\
7 & $\mathrm{a}_{3} \mathrm{~b}_{1}$ & 40 & 60 & 20 & 0,5 \\
8 & $\mathrm{a}_{3} \mathrm{~b}_{2}$ & 40 & 60 & 20 & 1,0 \\
9 & $\mathrm{a}_{3} \mathrm{~b}_{3}$ & 40 & 60 & 20 & 1,5 \\
\hline
\end{tabular}

\section{HASIL DAN PEMBAHASAN}

Hasil analisa daya hambat terhadap produk antiseptik pencuci tangan dengan menggunakan asap cair cangkang sawit sebagai bahan antiseptik ditunjukkan pada Tabel 2.

Berdasarkan hasil analisa daya hambat terhadap pertumbuhan bakteri, viscositas dan $\mathrm{pH}$ antara 3,5-4,0 menunjukkan bahwa antiseptik mempunyai peranan sebagai daya hambat bakteri pada kondisi asam asetat asam propionat asam butirat, asam valerat dan asam isokapronat, komponen aktif yang berperan terhadap daya hambat bakteri adalah asam asetat (Darmadji et al, 2012). Senyawa asam terutama asam asetat mempunyai aktivitas antimikroba dan pada konsentrasi $5 \%$ mempunyai efek bakterisidal.
Berdasarkan hasil analisa kandungan asam asetat pada asap cair cangkang sawit hasil pirolisis dan pemurnian dengan redistilasi pengendapan dan penyaringan dan asap cair tanpa proses pemurnian dihasilkan asam asetat 2,99\%-63,93\% relatif komponen (Fauziati, 2011). Berdasarkan hasil analisa kandungan asam asetat pada asap cair cangkang sawit hasil pirolisis dan pemurnian dengan redistilasi pengendapan dan penyaringan dan asap cair tanpa proses pemurnian dihasilkan asam asetat 2,99\%-63,93\% relatif komponen (Fauziati, 2011). Asam asetat bersifat mampu menembus dinding sel dan secara efisien mampu menetralisir gradient $\mathrm{pH}$ transmembran. Hasil analisa daya hambat terhadap pertumbuhan bakteri untuk perlakuan $a_{1} b_{1}, a_{1} b_{2}, a_{1} b_{3}$ $a_{2} b_{1}$ dan $a_{2} b_{2}$ destilasi kisaran suhu $180^{\circ} \mathrm{C}-200{ }^{\circ} \mathrm{C}$ pada perbandingan asap cair dan alkohol 40\%: 60\% tidak memberikan daya hambat terhadap pertumbuhan bakteri Staphylococcus aureus, Escheria colli dan Salmonella.

Perlakuan $a_{2} b_{3}$ memberikan zona hambat terhadap pertumbuhan bakteri $S$. aureus sebesar $10 \mathrm{~mm}$ dan S.tiphy sebesar $11 \mathrm{~mm}$ sedangkan untuk perlakuan $a_{3} b_{1}$ (pengental $20 \%$ dan pelembut $0,5 \%$ ), $a_{3} b_{2}$ (pengental $20 \%$ dan pelembut $1,0 \%$ ) dan $a_{3} b_{3}$, (pengental $20 \%$ dan pelembut $1,5 \%$ ) masing-masing memberikan zona hambat terhadap pertumbuhan bakteri $S$, aureussebesar 10 $\mathrm{mm}$. Pada kondisi yang sama hasil analisa daya hambat terhadap pertumbuhan bakteri asap cair sebagai bahan antiseptik pada formulasi $40 \%$ asap cair dan $60 \%$ alkohol tanpa penambahan bahan aditif pengental (polygel) dan pelembut (glyserin) rata-rata memberikan zona hambat sebesar $8 \mathrm{~mm}$ pada bakteri $S$ .aureus dan $8 \mathrm{~mm}$ untuk jenis bakteri S.tiphy (Fauziati, 2011).

Sedangkan hasil analisa daya hambat terhadap pertumbuhan bakteri untuk perlakuan destilasi kisaran suhu $180^{\circ} \mathrm{C}-200^{\circ} \mathrm{C}$ pada perbandingan asap cair dan alkohol 40\%:60\% dengan 
penambahan pengental $16 \%$ dan pelembut $1,50 \% \quad\left(a_{2} b_{3}\right)$ memberikan zona hambat terhadap pertumbuhan bakteri $S$. Aureus sebesar $10 \mathrm{~mm}$ kategori kuat dan daya hambat terhadap pertumbuhan bakteri Salmonella tiphy sebesar $11 \mathrm{~mm}$, dengan kategori kuat.
Sehingga pada kondisi $\mathrm{pH}$ 3,5 dan konsentrasi pengental $16 \%$ dan pelembut $1,5 \% \quad\left(a_{2} b_{3}\right)$ memberikan daya hambat terhadap pertumbuhan bakteri yang tinggi yaitu $11 \mathrm{~mm}$ khususnya untuk jenis bakteri

Tabel 2 : Analisa Daya Hambat Terhadap Produk Antiseptik Pencuci Tangan Dengan Menggunakan Asap Cair Sebagai Bahan Antiseptik .

\begin{tabular}{|c|c|c|c|c|r|r|r|r|c|}
\hline \multirow{2}{*}{ No } & \multirow{2}{*}{$\begin{array}{c}\text { Perla } \\
\text { kuan }\end{array}$} & \multicolumn{2}{|c|}{$\begin{array}{c}\text { Staphilococus } \\
\text { aureus }\end{array}$} & \multicolumn{2}{c|}{ Escheria colli } & \multicolumn{2}{c|}{ Salmonella } & pH & Viscositas dPas \\
\cline { 3 - 10 } & & $\mathrm{A} / \mathrm{T}$ & Zona (mm) & $\mathrm{T} / \mathrm{T}$ & $\begin{array}{c}\text { Zona/ } \\
\mathrm{mm}\end{array}$ & $\mathrm{A} / \mathrm{T}$ & $\begin{array}{c}\text { Zona/ } \\
\mathrm{mm}\end{array}$ & & \\
\hline 1 & $\mathrm{a}_{1} \mathrm{~b}_{1}$ & $\mathrm{~T}$ & - & $\mathrm{T}$ & - & $\mathrm{T}$ & - & 3,5 & 0,35 \\
\hline 2 & $\mathrm{a}_{1} \mathrm{~b}_{2}$ & $\mathrm{~T}$ & - & $\mathrm{T}$ & - & $\mathrm{T}$ & - & 3,5 & 0,30 \\
\hline 3 & $\mathrm{a}_{1} \mathrm{~b}_{3}$ & $\mathrm{~T}$ & - & $\mathrm{T}$ & - & $\mathrm{T}$ & - & 3,5 & 0,45 \\
\hline 4 & $\mathrm{a}_{2} \mathrm{~b}_{1}$ & $\mathrm{~T}$ & - & $\mathrm{T}$ & - & $\mathrm{T}$ & - & 3,5 & 0,30 \\
\hline 5 & $\mathrm{a}_{2} \mathrm{~b}_{2}$ & $\mathrm{~T}$ & - & $\mathrm{T}$ & - & $\mathrm{T}$ & - & 3,5 & 0,58 \\
\hline 6 & $\mathrm{a}_{2} \mathrm{~b}_{3}$ & $\mathrm{~A}$ & 10 & $\mathrm{~T}$ & - & $\mathrm{A}$ & 11 & 3,5 & 0,40 \\
\hline 7 & $\mathrm{a}_{3} \mathrm{~b}_{1}$ & $\mathrm{~A}$ & 10 & $\mathrm{~T}$ & - & $\mathrm{T}$ & - & 4,0 & 0,32 \\
\hline 8 & $\mathrm{a}_{3} \mathrm{~b}_{2}$ & $\mathrm{~A}$ & 10 & $\mathrm{~T}$ & - & $\mathrm{T}$ & - & 3,5 & 0,38 \\
\hline 9 & $\mathrm{a}_{3} \mathrm{~b}_{3}$ & $\mathrm{~A}$ & 10 & $\mathrm{~T}$ & - & $\mathrm{T}$ & - & 3,5 & 0,35 \\
\hline
\end{tabular}

Keterangan : $\mathrm{T}=$ Tidak ada daya hambat, $\mathrm{A}=$ Ada daya hambat

Menurut Herwig (1979) dalam Pujilestari T (2010), bahwa suatu bahan memiliki daya hambat pertumbuhan bakteri/ mikroba sangat kuat bila diameter hambatnya $>20 \mathrm{~mm}$, kuat $10-20 \mathrm{~mm}$ dan sedang 5-10 mm serta lemah $<5 \mathrm{~mm}$ dan menurut Fauziati (2011), bahwa tanpa penambahan bahan aditif pada $a_{2} b_{3}$ untuk kedua jenis bakteri menunjukkan daya hambat sebesar $8 \mathrm{~mm}$ (kategori sedang) sehingga ada kenaikan daya hambat terhadap pertumbuhan bakteri.dengan penambahan bahan aditif pengental dan pelembut tersebut.

Hal tersebut menunjukkan bahwa peranan bahan additif pengental polyglicol dan pelembut gliserin memberikan daya hambat terhadap pertumbuhan bakteri dimana gliserin disamping digunakan sebagai humectan (pelembab) juga sebagai pelembut dan juga berfungsi sebagai bakteriostastic (Lewis RJ., Sr, 2002). Sehingga dengan penambahan bahan aditif pengental dan pelembut memberikan daya hambat terhadap pertumbuhan bakteri dengan kategori kuat ,dengan penambahan pengental $16 \%$ dan pelembut $1,50 \% \quad\left(a_{2} b_{3}\right)$, dengan zona hambat terhadap pertumbuhan bakteri Staphylococcus aureus sebesar $10 \mathrm{~mm}$ dan daya hambat terhadap pertumbuhan bakteri Salmonella sebesar $11 \mathrm{~mm}$, sedangkan menurut Fauziati (2011), bahwa pada kondisi yang sama $\left(a_{2} b_{3}\right)$ tanpa penambahan bahan aditif pada kedua jenis bakteri menunjukkan daya hambat sebesar $8 \mathrm{~mm}$ (kategori sedang), sehingga ada kenaikan daya hambat terhadap bakteri dan untuk perlakuan destilasi kisaran suhu $180-200{ }^{\circ} \mathrm{C}$ dengan perbandingan asap cair dan alkohol $40 \% \quad: 60 \%$ dengan menggunakan bahan pengental $20 \%$ dan pelembut $0,5 \%, 1.0 \%$ dan $1,5 \% \quad\left(a_{3} b_{1}\right.$, $a_{3} b_{2}$ dan $a_{3} b_{3}$ ) memberikan zona hambat terhadap pertumbuhan bakteri Staphilococus aureus. Menurut (Fauziati, 2011) dalam Pemanfaatan Asap cair Cangkang Sawit Sebagai Bahan Antiseptik Pembersih Tangan ,bahwa sebelum penambahan bahan additif memberikan daya hambat dengan kategori 
sedang dengan diameter hambatnya sebesar $8 \mathrm{~mm}$, sehingga terjadi kenaikan daya hambat terhadap pertumbuhan bakteri. Sedangkan fungsi dari gliserin adalah disamping sebagai humectan (pelembab) juga berfungsi sebagai bacteriostatics (Lewis RJ.,Sr, 2002).

Glyserin dengan rumus kimia $\mathrm{C}_{3} \mathrm{H}_{6} \mathrm{OH}$ adalah senyawa kimia jernih ,tidak berwarna, agak kental hygroskopis, larut dalam air dan alkohol, tidak larut dalam eter, benzene dan kloroform dan bersifat volatile digunakan sebagai plastisiser, kosmetik, khusus untuk sabun, bakteriostatik yaitu senyawa yang berperan menghambat laju pertumbuhan bakteri dan sebagai antifreezes. Sehingga dengan penambahan bahan aditif polygel sebagai pengental dan glyserin sebagai pelembut memberikan pengaruh terhadap kemampuan daya hambat terhadap bakteri khususnya Staphylococus aureus dan Salmonella dengan diameter daya hambat lebih besar $10 \mathrm{~mm}$. (Pujilestari T, 2010 dalam Herwig 1979).

Untuk mengetahui kemampuan daya hambat produk antiseptik pencuci tangan dengan bahan antiseptik asap cair cangkang sawit dengan penambahan bahan additif pengental dan pelembut terhadap pertumbuhan bakteri maka dilakukan uji swab test .

Hasil analisa Swab test untuk produk antiseptik hasil penelitian seperti pada Gambar 2.

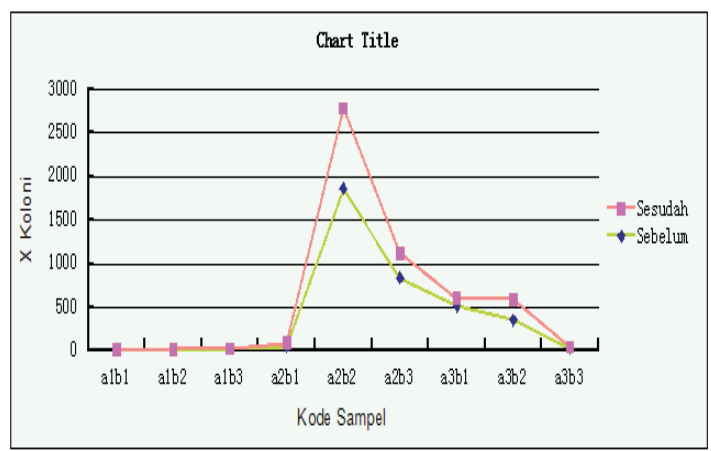

Gambar 2. Grafik Analisa Sawb Test

Keterangan : bahwa masing-masing kode sampel dilakukan analisa terhadap 3 (tiga) orang panelis.
Dari hasil uji swab tes terhadap 27 (dua puluh tujuh) tangan panelis sebelum dan sesudah diusap dengan produk antiseptik pencuci tangan berbahan antiseptic asap cair cangkang sawit menunjukkan perbedaan jumlah koloni sebelum diusap dan sesudah diusap terhadap produk antiseptik berbahan asap cair cangkang sawit dengan bahan aditif pengental polyglicol dan pelembut glyserin dan terjadi adanya pengurangan jumlah koloni bakteri sebelum dan sesudah diusap sebelum diusap 8,3\% dan setelah diusap terjadi pengurangan jumlah koloni sebesar $96,75 \%$. Hal ini menunjukkan bahwa komponen aktif asap cair yang terdapat pada antiseptik pembersih tangan dan adanya penambahan bahan aditif sebagai pengental (polyglicol) dan sebagai humectan dan pelembut (glyserin) sebagai humectans dan bacteriostatics berpengaruh terhadap pengurangan jumlah bakteri koloni yang diusap pada tangan panelis sebelum dan sesudah diusap , karena unsur utama pada asap cair yang mempunyai peranan terhadap antiseptik yaitu alkohol sebagai desenfektan ,phenol sebagai anti oksidan dan asam asetat sebagai daya hambat terhadap pertumbuhan bakteri, dan $\mathrm{pH}$ larutan yang rendah mempunyai peranan terhadap daya hambat pertumbuhan bakteri (Darmadji $\mathrm{P}$ et al ,2012 dan Lewis RJ,SR, 2002 dan Anonim 2010) .

\section{KESIMPULAN}

Asap cair cangkang sawit dapat digunakan sebagai bahan antiseptik pencuci tangan. Pada penambahan bahan pengental $16 \%$ dan pelembut $1,50 \%$ memberikan daya hambat pada pertumbuhan bakteri yang terbaik terhadap bakteri Staphylococus aureus dengan kategori kuat dan bakteri Salmonella thipy dengan kategori kuat dengan $\mathrm{pH}$ sebesar 3,5 dan viscositas sebesar 0,4 dPas. Adanya perubahan jumlah koloni 
bakteri sebelum dan sesudah diusap dengan produk pencuci tangan berbahan antiseptik asap cair terhadap tangan panelis sebelum diusap $8,3 \%$ dan sesudah diusap $96,75 \%$

\section{DAFTAR PUSTAKA}

Anonim,2010 , Perbedaan Daya Hambat Kitosan Blangkas ( Lymulus Polyphemus ) Bermolekul Tinggi Dengan Pelarut Gliserin Dan VCO Terhadap Fusobacterium nucleatum ATTC 25586( Penelitian In Vitro ) http://respository.usu.ac.id/handle/1 23456789/8332 15 Januari 2012

Bappeda Propinsi Kalimantan Timur ,2013, Data Potensi Kelapa Sawit Di Kalimantan Timur.

Dinas Perkebunan Propinsi Kalimantan Timur, 2010, Laporan Data Produksi Hasil Perkebunan .

Darmadji $P$ et al,2002. Perbandingan Pengasapan Panas Dan Penggunaan Asap Cair Pada Pengolahan Ikan; Tinjauan Kandungan Benzopirin, Fenol dan Sifat Organoleptik Ikan Asap. Agritech, Fakultas Teknologi Pertanian, Universitas Gajah Mada Yogyakarta .

Darmaji, P,et al ,2012, Inovasi Prototipe Produk Nanoenkapsulasi Biopreservatif Asap Cair Sebagai Pengawet Pangan Alami pada Seminar Insinas 2012. http://Insentif.ristek.go.id/PROSIDIN G/RT-2012-1001. htm 8 April 2014
Fauziati, 2011, Pemanfaatan Asap Cair Cangkang Sawit Sebagai Bahan Antiseptik Pencuci Tangan, Jurnal Riset Teknologi Industri Vol 5 No 10 Desember 2011.

Lewis, RJ.,Sr,2002. Hawley's Condensed Chemical Dictionary, Van Nostrand Reinhold Company, Fourteenth Edition New York.

Maksum et al, 2007, Uji Efektifitas Antimikroba Beberapa Merk Dagang Pembersih Tangan Antiseptik Majalah Ilmu Kefarmasian Vol IV ,No1 April 2007 FMIPA UI

Marpaung, DS.2009. Pemanfaatan Limbah Pabrik Kelapa Sawit Sebagai Pembangkit Listrik. http://Dedy Suhendra Marpaung. Blok.spot.com, Oktober, 2009

Pujilestari T, 2010, Sifat Fisiko Kimia Asap Cair Dari Limbah Kelapa Sawit Balai Riset Dan Standardisasi Industri Samarinda.

Rahmi N. dan Pujilestari T, 2008. Aktivitas Anti Bakteri Dari Cuka Kayu Pohon Akasia, Karet dan Galam. Warta Balai Industri Banjarbaru. Vol XXIII. No 2, hal 21-25. Balai Riset dan Standardisasi Industri Banjarbaru.

Rostinawati T, 2009, Aktivitas Antibakteri Ekstrak etanol Bunga Rosella (Hibiscus sabdarifa L) Terhadap E. colli, Salmonella typhi dan Staphilococus aureus Dengan Metoda Difusi Agar ,Fakultas Farmasi Universitas Padjadjaran Jatinagor 